\title{
A família Boraginaceae sensu lato na APA Serra Branca/Raso da Catarina, Bahia, Brasil \\ Boraginaceae sensu lato in the APA Serra Branca/Raso da Catarina, Bahia, Brazil
}

\author{
Diego Daltro Vieira ${ }^{1}$, Adilva de Souza Conceição ${ }^{1,4}$, José Iranildo Miranda de Melo ${ }^{2}$ \\ \& María Natividad Sánchez de Stapf ${ }^{3}$
}

\begin{abstract}
Resumo
Este trabalho consiste no levantamento florístico da família Boraginaceae na APA Serra Branca/Raso da Catarina, localizada no município de Jeremoabo, Bahia. Foram analisados espécimes coletados no período de Agosto/2009 a Junho/2011 e coleções herborizadas depositadas nos Herbários ALCB, HRB e HUEFS. Foram encontrados quatro gêneros e dez espécies de Boraginaceae: Cordia rufescens A.DC., C. trichotoma (Vell.) Arráb. ex Steud., C. glabrata (Mart.) A.DC., Heliotropium angiospermum Murray, H. elongatum (Lehm.) I.M.Johnst., Tournefortia rubicunda Salzm. ex DC., T. salzmannii DC., Varronia curassavica Jacq., V. globosa Jacq. e $V$. leucocephala (Moric.) J.S.Mill. São apresentadas chaves para identificação de gêneros e espécies, descrições, ilustrações, comentários sobre distribuição geográfica e fenologia das espécies.

Palavras-chave: florística, semiárido, caatinga, Ecorregião Raso da Catarina.
\end{abstract}

\begin{abstract}
This work consists of a floristic survey of Boraginaceae in APA Serra Branca/Raso da Catarina, located in Jeremoabo, Bahia, Brazil. We analyzed specimens collected between August 2009 and June 2011 and collections deposited in the ALCB, HRB and HUEFS herbaria. Four genera and ten species of Boraginaceae were found: Cordia rufescens A.DC., C. trichotoma (Vell.) Arráb. ex Steud., C. glabrata (Mart.) A.DC., Heliotropium angiospermum Murray, H. elongatum (Lehm.) I.M.Johnst., Tournefortia rubicunda Salzm. ex DC., T. salzmannii DC., Varronia curassavica Jacq., $V$. globosa Jacq. e $V$. leucocephala (Moric.) J.S.Mill. Keys for identification of genera and species, descriptions, illustrations and comments about geographic distribution and phenology of the species are presented.
\end{abstract}

Key words: floristic, semiarid, caatinga, Ecoregion Raso da Catarina.

\section{Introdução}

Boraginaceae sensu lato possui cerca de 134 gêneros e 2.650 espécies. Seus representantes distribuem-se nas regiões tropicais, subtropicais, temperadas e árticas, com centros de dispersão localizados nas regiões mediterrâneas e nos Estados Unidos da América (Al-Shehbaz 1991; Judd et al. 2009).

No Brasil ocorrem nove gêneros e aproximadamente 125 espécies, sendo Cordia, Varronia e Tournefortia os gêneros mais numerosos.
Na Região Nordeste, na vegetação da caatinga, a família se destaca por concentrar seis gêneros e 39 espécies, o que corresponde a $2,7 \%$ do número de espécies deste bioma (Giulietti et al. 2006; Melo et al. 2010).

$\mathrm{O}$ primeiro e mais abrangente tratamento taxonômico para a família no Brasil foi elaborado por Fresenius (1857) na Flora brasiliensis, onde foram descritas 145 espécies reunidas em nove gêneros. Os trabalhos com o grupo, no Brasil, envolvem levantamentos florísticos ou

\footnotetext{
${ }^{1}$ Universidade do Estado da Bahia, Depto. Educação, Herbário HUNEB (Coleção Paulo Afonso), Campus VIII, R. do Gangorra 503, CHESF, Alves de Sousa, 48608-240, Paulo Afonso, BA, Brasil.

${ }^{2}$ Universidade Estadual da Paraíba, Centro de Ciências Biológicas e da Saúde, Depto. Biologia, Av. das Baraúnas 351, Campus Universitário, 58429-500, Campina Grande, PB, Brasil.

${ }^{3}$ Smithsonian Tropical Research Institute, Apartado 0843-03092, Balboa, Panamá, República de Panamá.

${ }^{4}$ Autor para correspondência: adilva.souza@gmail.com
} 
revisões de gêneros, podendo ser destacados: Smith (1970), Guimarães et al. (1971), Taroda (1984), Taroda \& Gibbs (1986a, b, 1987), Taroda \& Silva (2002), Cavalheiro et al. (2003), Melo (2007a), Stapf (2007) e Cavalheiro et al. (2011). Estudos sobre levantamentos florísticos para família Boraginaceae na Região Nordeste foram realizados por: Melo \& Sales (2004, 2005), Melo (2007b), Melo \& Andrade (2007), Melo et al. (2007), Freitas et al. (2008), Melo \& Lyra-Lemos (2008) e Melo et al. (2009).

Gürke (1893) subdividiu a família em cinco subfamílias: Boraginoideae Arn., Cordioideae (Link) Cham., Ehretioideae (Mart.) Arn., Heliotropioideae (Schrad.) Arn. e Wellstedioideae Pilger, tratamento adotado pela maioria dos estudiosos. Estudos filogenéticos, utilizando DNA de cloroplasto, propuseram a elevação das cinco subfamílias ao nível de família (Böhle \& Hilger 1997).

Apesar de haver uma proposta mais atual, baseada em dados estruturais e moleculares para a circunscrição da família, nesse estudo será adotado o conceito tradicional, considerando Boraginaceae sensu lato. Essa decisão deu-se pelo fato dos estudos com base em sequências moleculares ainda não apresentarem dados conclusivos sobre uma nova circunscrição para os subgrupos da família. Contudo, os gêneros Cordia e Varronia, os quais equivalem a Cordia sensu lato, serão reconhecidos aqui, como distintos, adotando os tratamentos de Borhidi et al. (1988) e Miller \& Gottschling (2007).

O presente trabalho teve como objetivo realizar o levantamento das espécies da família Boraginaceae ocorrentes na APA Serra Branca/ Raso da Catarina, visando contribuir para o conhecimento da flora do estado da Bahia, bem como, fornecer subsídios para o desenvolvimento do plano de manejo da APA.

\section{Material e Métodos}

A Área de Proteção Ambiental (APA) Serra Branca/Raso da Catarina (Fig. 1) localiza-se no município de Jeremoabo, Nordeste da Bahia, totalmente inserida no "polígono das secas", com uma área de 67.237 ha, delimitada pelas coordenadas $09^{\circ} 53$ ' 15,5 " a $09^{\circ} 44^{\prime} 34,6^{\prime}$ 'S e $38^{\circ} 49^{\prime} 36,1^{\prime \prime}$ 'a $38^{\circ} 52^{\prime} 20,4$ '” $\mathrm{W}$, limitando-se ao sul com o rio Vaza-Barris e ao norte com a Estação Ecológica (ESEC) Raso da Catarina. A área compreende a Unidade Geomorfológica Tabuleiro Dissecado do Vaza Barris, apresentando como característica principal, os diferentes graus de

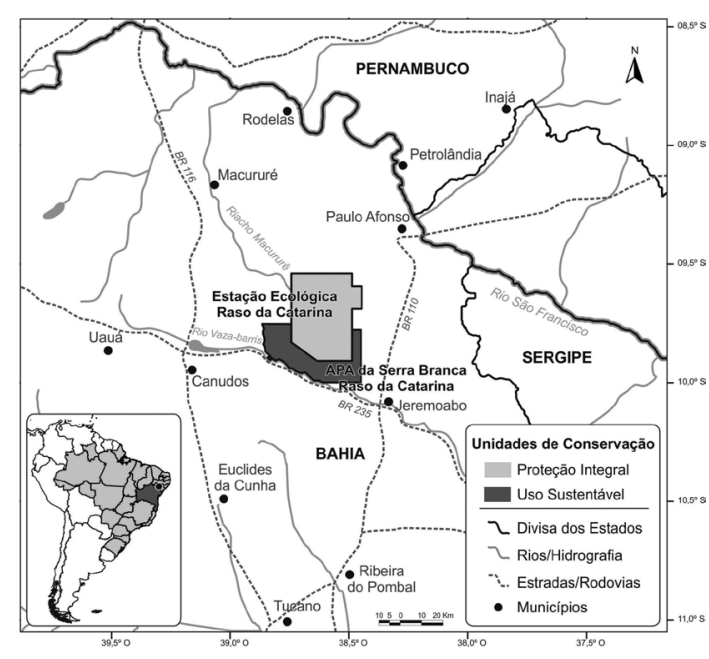

Figura 1 - Localização da APA Serra Branca/Raso da Catarina.

Figure 1 - Location of the APA Serra Branca/Raso da Catarina.

dissecação, associados a uma estrutura falhada e fraturada, evidenciada pela formação de paredões de arenito. As precipitações anuais variam em torno de $500 \mathrm{~mm}$ e a temperatura anual é de aproximadamente $23^{\circ} \mathrm{C}$ (Szabo et al. 2007).

As coletas de material botânico foram realizadas em 12 excursões, no período entre agosto/2009 e junho/2011, seguindo a metodologia de Fosberg \& Sachet (1965) e Mori et al. (1989), onde foram coletados materiais férteis com flores e/ou frutos e feitas observações sobre a distribuição das espécies e os tipo de solo (Sampaio 1995; Tricart 1972). Os espécimes foram depositados no herbário da Universidade do Estado da Bahia (HUNEB - Coleção Paulo Afonso) e as duplicatas enviadas para os principais herbários do estado da Bahia.

A identificação do material e a terminologia utilizada para descrição foram baseadas em bibliografia especializada (Johnston 1928, 1930; Harris \& Harris 2001), protológos, imagens de coleções-tipo e consulta às coleções dos herbários visitados: ALCB, HRB, HUEFS, MBM (Thiers 2011). A distribuição geográfica das espécies foi complementada pela lista elaborada por Melo et al. (2010, 2012). Os dados sobre fenologia são referentes às observações na área de estudo. $\mathrm{O}$ tratamento taxonômico inclui chave de identificação para gêneros e espécies, descrições, ilustrações, dados sobre distribuição geográfica e fenologia. 


\section{Resultados e Discussão}

Boraginaceae Juss., Gen. pl., p. 128. 1789.

Árvores, arbustos, subarbustos, lianas

ou ervas anuais ou perenes. Folhas alternas, subopostas ou mais raramente opostas, simples, desprovidas de estípulas, pecioladas ou sésseis, com diferentes formas. Inflorescências terminais, falsamente terminais ou axilares, paniculiformes, glomérulo-globosas, espiciformes, escorpioides ou helicoides. Flores com ou sem brácteas; corola hipocrateriforme, salverforme, tubular a tubularsalverforme ou ob-campanulada, verde, branca, creme, roxa ou alaranjada. Estames 5, epipétalos, alternos aos lobos da corola, inseridos geralmente na altura da metade inferior do tubo ou na fauce da corola; anteras livres ou coerentes entre si, introrsas ou extrorsas, apendiculadas ou desprovidas de apêndices, deiscência longitudinal. Gineceu 2 carpelos; ovário 2 ou 4-locular, pela intrusão de um falso septo, disco nectarífero presente ou ausente, discreto ou espessado. Placentação axilar ou basal; óvulos 1-2 por lóculo, anátropos ou hemianátropos. Frutos secos ou carnosos, deiscentes ou indeiscentes, drupáceos ou esquizocárpicos constituídos por mericarpos (núculas). Sementes 1-2 por loco, embrião plano ou curvo.

Foram registradas para APA, dez espécies, representando quatro gêneros, dos quais Cordia e Varronia, ambos com três espécies, foram os mais representativos. As espécies predominantes na área foram: $V$. globosa Jacq., $V$. curassavica Jacq. e C. rufescens A.DC., as quais estão diretamente associadas aos solos arenosos com baixa capacidade de retenção de água. As espécies menos predominantes foram: C. trichotoma (Vell.) Arráb. ex Steud. e C. glabrata (Mart.) A.DC., associadas aos solos argilosos ou areno-argilosos, os quais possuem maior capacidade de retenção de água.

\section{Chave de identificação para gêneros e espécies de Boraginaceae da APA Serra Branca}

1. Inflorescências paniculiformes, espiciformes ou glomérulo-globosas; estilete 2 vezes bifurcado; ramos estigmáticos 4; fruto com 1 semente.

2. Árvores ou arbustos, raramente subarbustos; folhas com margem inteira ou irregularmente crenada a denteada na porção apical; inflorescências paniculiformes 1. Cordia

3. Cálice rufo, não costado; corola ca. $4 \mathrm{~cm}$, decídua 1.2 C. rufescens

3'. Cálice verde, costado; corola $1,2-2,5 \mathrm{~cm}$, marcescente.

4. Folhas ovais, elípticas a obovais com tricomas estrelados; flor ca. $1,9 \mathrm{~cm}$; lobos da corola subtruncados 1.3. C. trichotoma

4'. Folhas elípticas, ovais a orbiculares com tricomas simples; flor 3-3,5 cm; lobos da corola orbiculares 1.1. C. glabrata

2'. Arbustos ou subarbustos; folhas com margem serreada; inflorescências espiciformes ou gloméruloglobosas

4. Varronia

5. Lâmina foliar com base atenuada; inflorescência espiciforme ................ 4.1. V. curassavica

5'. Lâmina foliar com base cuneada a truncada ou cuneada a obtusa; inflorescência glomérulo-globosa.

6. Cálice com ápice dos lacínios filiformes; corola de 2,5-5 $\mathrm{mm}$...... 4.2. V. globosa

6'. Cálice com ápice dos lacínios agudos; corola de 2,5-3,5 cm 4.3. V. leucocephala

1'. Inflorescências escorpioides; estigma inteiro; fruto com 4 sementes.

7. Anteras livres entre si; fruto seco, esquizocárpico

2. Heliotropium

8. Corola obcampanulada; estigma umbraculiforme; frutos depresso-globosos, verruculosos.. 2.1. H. angiospermum

8'. Corola tubular-salverforme; estigma clavado; frutos mitriformes, híspidos ....

7'. Anteras coerentes pelo ápice; fruto carnoso, drupáceo

3. Tournefortia

9. Tricomas foliares com base acentuadamente discoide; ovário obclavado; estigma subpeltado

3.1. T. rubicunda

9'. Tricomas foliares com base nunca discoide; ovário cônico-piramidal; estigma estreitamente cônico . 3.2. T. salzmannii 
1. Cordia L., Sp. pl. 1: 190. 1753.

Árvores ou arbustos, raramente subarbustos; ramos estrigosos, pubescentes ou vilosos, rufos ou não, com tricomas simples ou estrelados, geralmente lenticelados. Folhas alternas, dísticas ou espiraladas, pecioladas, persistentes ou decíduas, margem inteira ou irregularmente crenada a denteada na porção apical. Inflorescências paniculiformes, terminais e axilares, laxas ou congestas. Flores andróginas ou funcionalmente unissexuais, subsésseis ou sésseis; cálice gamossépalo, tubular, costado ou não, esparsamente estrigoso a tomentoso; corola alva, com ou sem máculas acastanhadas, marrom quando passada, hipocrateriforme, infundibuliforme ou salverforme, tomentosa, glabra a pubescente, lobos orbiculares ou subtruncados. Estames 5, raramente 6 (C. trichotoma), com filetes desenvolvidos, epipétalos; anteras livres, introrsas ou extrorsas. Ovário tetralocular, óvulos 4; estilete 2 vezes bifurcado; ramos estigmáticos 4 , capitados ou foliáceos. Fruto drupa, mucilaginosa, cálice persistente e acrescente. Semente 1, aristada ou globosa, embrião plano.

Cordia possui aproximadamente 250 espécies distribuídas nos trópicos e subtrópicos, com centro de diversidade nas Américas. No Brasil, o gênero está representado por 47 espécies, dentre essas, 11 ocorrem na caatinga (Miller \& Gottschling 2007; Melo et al. 2010). As espécies do gênero Cordia apresentam heterostilia, do tipo distilia e tristilia. Contudo, nos espécimes analisados na área não observamos este caráter.

\subsection{Cordia glabrata (Mart.) A.DC., Prodr. 9: 473. 1845. \\ Figs. 2a, 3a-d}

Árvore 4-6 m; ramos acinzentados, glabros. Folhas alternas espiraladas; lâmina 2,5-8 × 1,9-5,5, cartácea a semicoriácea, discolor, elíptica, oval a orbicular, ápice agudo a arredondado, margem inteira, base cuneada a arredondada, face adaxial glabrescente, face abaxial tomentosa, ambas com tricomas simples; pecíolo $0,8-1,6 \mathrm{~cm}$, tomentoso, venação broquidódroma. Inflorescência $3-12 \mathrm{~cm}$, panícula terminal, congesta, pedúnculo 1,7-2,6 $\mathrm{cm}$, tomentoso, eixo tomentoso. Flores 3-3,5 $\mathrm{cm}$, sésseis; cálice ca. $1,4 \mathrm{~cm}$, tubular, costado, verde, externamente tomentoso, internamente pubescente a seríceo, lacínios 1,5-2 × 0,9-1,1 $\mathrm{mm}$, lanceolados, ápice agudo; corola $2-2,5 \mathrm{~cm}$, salverforme a infundibuliforme, alva, marrom quando passada, marcescente, glabra, lobos 0,9-1,2 $\times 0,8-1 \mathrm{~cm}$, orbiculares; estames 5 , epipétalos, pubescentes na base, filetes $1,6-1,9 \mathrm{~cm}$, anteras ca. $3,6 \mathrm{~mm}$, oblongas; ovário ca. $3 \mathrm{~mm}$, subgloboso, disco nectarífero ca. $2 \mathrm{~mm}$; estilete ca. $1,5 \mathrm{~cm}$, estigmas ca. 1,5 mm, foliáceos. Drupa ca. $0,7 \mathrm{~mm}$ compr. $\times$ 3-4,2 mm diâm, ovoide, marrom, glabra a pubescente. Semente 1, ca. $4 \mathrm{~mm}$ compr. $\times$ ca. 3 mm diâm, globosa.

Material examinado: Fazenda Serra Branca, Trilha em direção ao Tanque de Coleta, 5.XI.2010, fl. e fr., L.R. Silva 12 (HUNEB).

Material adicional: BRASIL. BAHIA: Canudos, cerca de $5 \mathrm{~km}$ de Canudos, 12.VIII.2004, fr., A.A. Santos et al. 2442 (HUEFS). Curaçá, Riacho dos Marinhos, 8.VIII.1983, fl., G.C.P. Pinto \& S.B. da Silva 179/83 (HRB). Glória, Reserva Indígena Pankararé, 16.I.1993, fl. e fr., F.P. Bandeira 148 (ALCB). Serra de Itaparica, 16.VII.2007, fl. e fr., A.S. Conceição 1066 (HUEFS). Irecê, 18.V.1957, fl. e fr., R.P. Lordêlo 57357 (ALCB); Itatim, Morro do Agenor, 29.IX.1996, fl., F. França 1873 (ALCB). Jeremoabo, estrada $30 \mathrm{~km}$ antes de Paulo Afonso, 08.X.1961, fl., A. Lima 78236 (HUEFS). Paulo Afonso, estrada para o Raso da Catarina, 24.X.1982, fl., M.L. Guedes 550 (ALCB). Lajedo Alto, 25.IX.1984, fl., L.R. Noblick \& M.J. Lemos 3402 (HUEFS). Tucano, Povoado Bizamum ca. $23 \mathrm{~km}$ de Tucano, 18.VIII.2004, fl., D. Cardoso \& J. Vasconcelos-Neto 104 (HUEFS).

No Brasil, essa espécie encontra-se distribuída no Norte (Pará), Nordeste (Piauí e Bahia), CentroOeste (Mato Grosso, Goiás e Mato Grosso do Sul) e Sudeste (Minas Gerais), em ambientes de floresta amazônica, caatinga e cerrado (Melo et al. 2010). $\mathrm{Na}$ área de estudo, a espécie foi coletada uma única vez com flores e frutos, no mês de novembro. Dentre as espécies congêneres na área de estudo, C. glabrata assemelha-se a C. trichotoma pelo hábito e pela presença do cálice costado e corola marcescente. No entanto, a primeira espécie apresenta folhas elípticas, ovais a orbiculares, decíduas, com face adaxial lustrosa, tricomas simples, lobos da corola orbiculares e flores com aroma adocicado, enquanto que a segunda, apresenta folhas ovais, elípticas a obovais, tricomas estrelados, lobos da corola subtruncados e aroma das flores desagradável.

1.2. Cordia rufescens A.DC., Prodr. 9: 476. 184.

Figs. 2b, 3e-h

Arbusto, 0,3-2 m; ramos sulcados, geralmente rufos, vilosos. Folhas alternas espiraladas; lâmina 3-18 × 2-9 cm, cartácea a semicoriácea, discolor, elíptica a oboval, ápice agudo ou arredondado, margem inteira, crenada a denteada apenas na porção apical, base cuneada, face adaxial estrigilosa, face abaxial tomentosa, rufa; pecíolo 

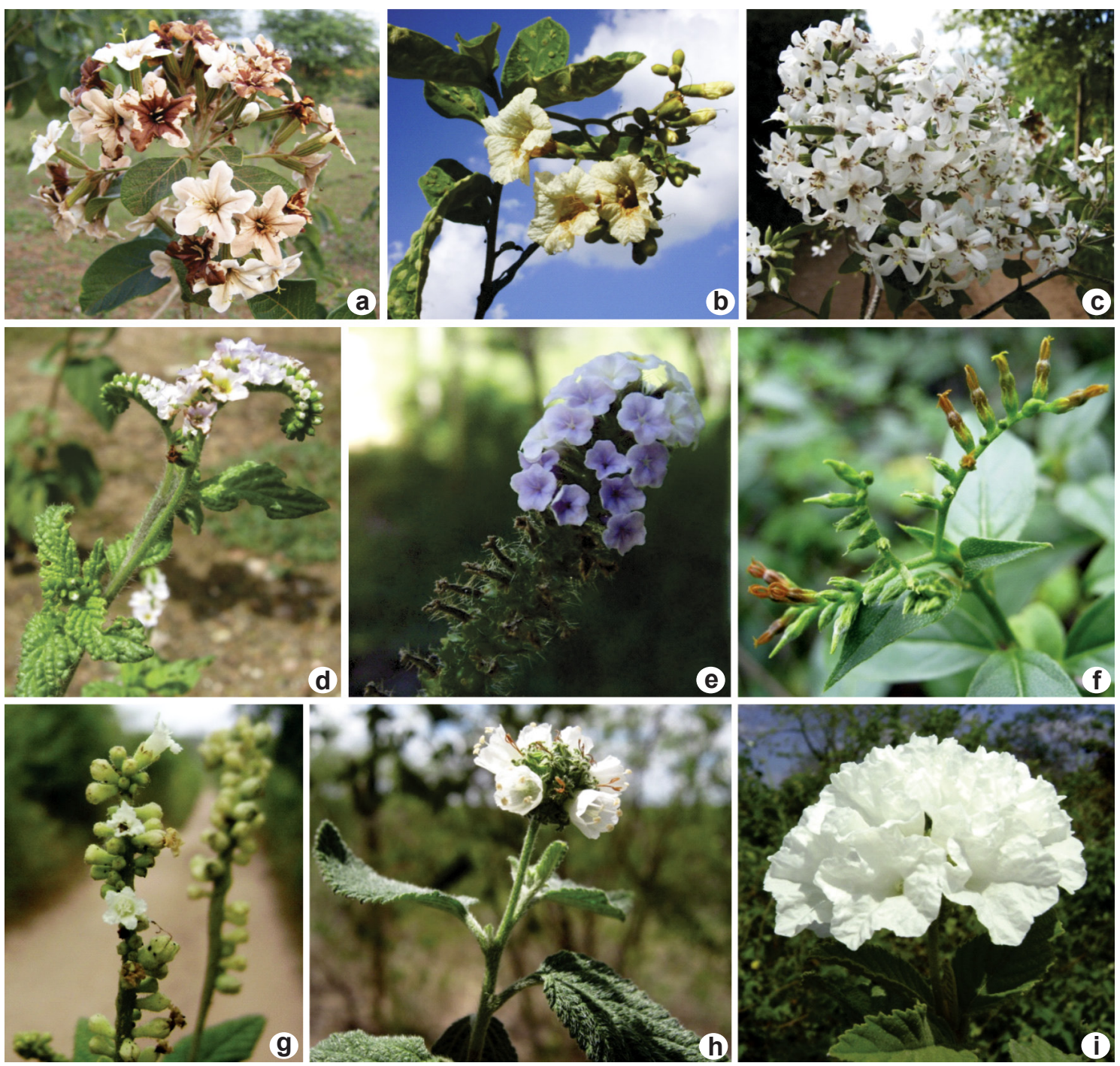

Figura 2 - a. Cordia glabrata (Mart.) A.DC.; b. Cordia rufescens A.DC.; c. Cordia trichotoma (Vell.) Arráb. ex Steud.; d. Heliotropium angiospermum Murray; e. Heliotropium elongatum (Lehm.) I.M.Johnst.; f. Tournefortia rubicunda Salzm. ex DC.; g. Varronia curassavica Jacq.; h. Varronia globosa Jacq.; i. Varronia leucocephala (Moric.) J.S.Mill. Figure 2 - a. Cordia glabrata (Mart.) A.DC.; b. Cordia rufescens A.DC.; c. Cordia trichotoma (Vell.) Arráb. ex Steud.; d. Heliotropium angiospermum Murray; e. Heliotropium elongatum (Lehm.) I.M.Johnst.; f. Tournefortia rubicunda Salzm. ex DC.; g. Varronia curassavica Jacq.; h. Varronia globosa Jacq.; i. Varronia leucocephala (Moric.) J.S.Mill.

0,3-1,2 cm, tomentoso; venação broquidódroma. Inflorescência $2-14 \mathrm{~cm}$, panícula terminal, laxa, pedúnculo 1,5-5,2 $\mathrm{cm}$, tomentoso, eixo híspido. Flores 3,5-5 cm, sésseis; cálice 1-1,4 cm, tubular, não costado, rufo, externamente tomentoso, internamente estrigiloso, lacínios 3-3,5 × 3-4 $\mathrm{mm}$, ovais a depresso-ovais, levemente desiguais entre si; corola ca. $4 \mathrm{~cm}$, infundibuliforme, alva, com máculas acastanhadas, decídua, externamente estrigilosa, internamente glabrescente, lobos ca. 0,9 $\times 1,8 \mathrm{~cm}$, orbiculares; estames 5 , epipétalos, vilosos até a metade do seu comprimento, filetes 1,2-1,7 $\mathrm{cm}$, anteras ca. $3 \mathrm{~mm}$, oblongas; ovário ca. $2 \mathrm{~mm}$, subgloboso, disco nectarífero ausente; estilete ca. 2,8 cm, estigmas ca. 0,2 mm, capitados. Drupa 1,3-1,9 cm compr. × ca. 1 cm diâm., ovoide, ápice 


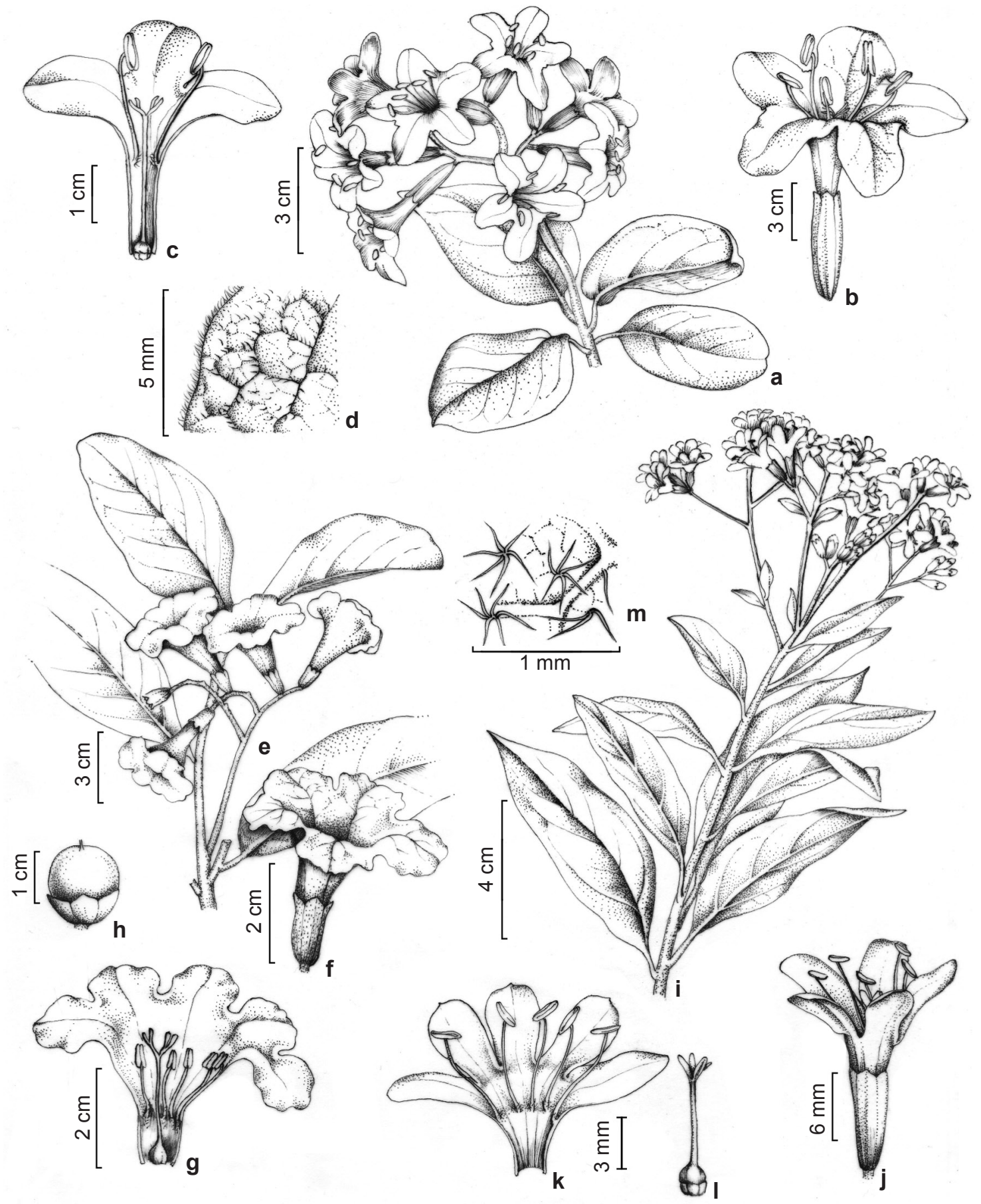

Figura 3 - a-d. Cordia glabrata (Mart.) A.DC. - a. ramo florífero;b. flor; c. seção longitudinal da flor, evidenciando androceu e gineceu; d. tricomas simples, face adaxial da folha (L.R. Silva 12). e-h. Cordia rufescens A.DC. - e. ramo florífero; f. flor; g. seção longitudinal da flor, evidenciando androceu e gineceu; h. fruto (A.S. Conceição 292). i-m. Cordia trichotoma (Vell.) Arráb. ex Steud. - i. ramo florífero; j. flor; k. seção longitudinal da flor, evidenciando androceu; 1. gineceu; m. tricomas estrelados, face adaxial da folha (D.D. Vieira 97).

Figure 3 -a-d. Cordia glabrata (Mart.) A.DC. - a. fertile branch; b. flower; c. longitudinal section of flower, showing androecium and gynoecium; d. simple trichomes, upper surface leaf(L.R. Silva 12). e-h. Cordia rufescens A.DC. - e. fertile branch; f. flower; g. longitudinal section of flower, showing androecium and gynoecium; h. fruit (A.S. Conceição 292). i-m. Cordia trichotoma (Vell.) Arráb. ex Steud. - i. fertile branch; j. flower; $\mathrm{k}$. longitudinal section of flower, showing androecium; 1. gynoecium; m. stellate trichomes, upper surface leaf (D.D. Vieira 97). 
apiculado, verde a enegrecida quando madura. Semente 1, ca. 1,5 cm compr. × 0,8 mm diâm., aristada, reticulada.

Material examinado: APA Serra Branca, Baixa Grande, Próximo ao povoado de Quelés, 19.III.2009, fl. e fr., A.S. Conceição 1556 (HUNEB); Estrada saindo de Quelés, sentido Estação Ecológica Raso da Catarina, 29.VII.2009, fl. e fr., A.S. Conceição 1802 (HUNEB); 17.VI.2009, fl., D.D. Vieira 01 (HUNEB); 8.IX.2009, fl. e fr., M.V.V. Romão 540 (HUNEB); 08.XII.2009, fl., D.D. Vieira 52 (HUNEB); Limite entre a APA Serra Branca e a Estação Ecológica Raso da Catarina, 17.VI.2009, fl., A.S. Conceição 1654 (HUNEB).

Material adicional: BRASIL. BAHIA: Barra, 6.IV.1978, fl., J.S. Assis et al. 137 (HRB); Entre Cipó e Pombal, 19.I.1964, fl., A.L. Costa 3500 (ALCB). Euclides da Cunha, Fazenda Santa Rosa, 18.VIII.2003, fr., M.L. Guedes et al. 10563 (ALCB); Sítio do Jaime, 21.IV.2004, fl., M.L. Guedes et al. 11459 (ALCB). Paulo Afonso, Estação Ecológica Raso da Catarina, 31.I.2006, fl., M.M.M. Lopes et al. 463 (HUEFS). Quixaba, caminho para Itupiara a $43 \mathrm{~km}, 25 . \mathrm{I} .2001$, fl., M.L. Guedes et al. 7924 (ALCB). Santa Brígida, Raso da Catarina, 28.VI.2002, fl., L.P. Queiroz et al. 7278 (HUEFS). Tucano, Fazenda Boqueirão, 5.I.2006, fl., J.M.O. Santos 936 (HUEFS); Fazenda Tabuleiro, 17.III.1998, fl., M.A. Batista et al. 04 (ALCB); 29.XII.2004, fl., J.M.O. Santos 190 (HUEFS). Sítio do Mandacaru, 15.IV.2006, fl., D. Cardoso \& M. Guerreiro 1210 (HUEFS).

Cordia rufescens é endêmica do Brasil, com registro para as Regiões Nordeste, Sudeste e Sul do país (Johnston 1930). Na Região Nordeste ocorre nos estados do Maranhão, Piauí, Ceará, Paraíba, Pernambuco, Bahia e Alagoas (Melo et al. 2010). $\mathrm{Na}$ área de estudo a espécie é abundante, encontrada em zona de transição entre a vegetação de caatinga e mata, na borda de ambientes de mata e, em áreas em processo de regeneração de queimadas. Foi coletada com flores entre os meses de junho e dezembro e com frutos nos meses de setembro a janeiro. Essa espécie possui características bastante distintivas das demais espécies encontradas na área, podendo ser facilmente reconhecida pelos ramos geralmente rufos, folhas crenadas até denteadas apenas na porção apical, inflorescências paniculiformes laxas, flores com cálice tomentoso, rufo, não costado, corola infundibuliforme alva, com máculas acastanhadas, decídua e frutos ovoides com ápice apiculado.

1.3. Cordia trichotoma (Vell.) Arráb. ex Steud., Nom. ed. 2: 419. 1840. Figs. 2c, 3i-m

Árvore, 4-10 m; ramos com fissuras longitudinais, tricomas estrelados, lenticelas esbranquiçadas. Folhas alternas espiraladas; lâmina 3-12,7 × 1,2-4,5 cm, cartácea a semicoriácea, discolor, oval, elíptica a oboval, ápice agudo a acuminado, base atenuada a cuneada, margem inteira, face adaxial estrigosa, ferrugínea, face abaxial pubescente, ambas com tricomas estrelados, mais acentuados nas nervuras; pecíolo 0,4-1,5 cm, pubescente; venação eucamptódroma. Inflorescência 3-14 cm, panícula terminal, congesta, pedúnculo 2-6 cm, pubescente, eixo com tricomas estrelados densamente distribuídos. Flores ca. 1,9 cm; subsésseis, pedicelo ca. 2 $\mathrm{mm}$; cálice $0,8-1 \mathrm{~cm}$, tubular, costado, verde, tomentoso, lacínios 1,4-1,8 × 0,4-1 mm, ovallanceolados, ápice mucronado; corola 1,2-1,7 $\mathrm{cm}$, hipocrateriforme, alva, marrom quando passada, marcescente, glabra, lobos ca. 9-4 mm, subtruncados; estames 5 (-6), epipétalos, tricomas pubescentes, hialinos na base, filetes $0,8-1 \mathrm{~cm}$, anteras ca. 3,5 mm, oblongas a lanceoladas; ovário ca. $2 \mathrm{~mm}$, subgloboso, disco nectarífero ca. $1 \mathrm{~mm}$; estilete ca. 1,1 cm, estigmas ca. $1 \mathrm{~mm}$, foliáceos. Fruto não observado.

Material examinado: APA Serra Branca, Estrada de acesso ao povoado Quelés, sentido Estação Ecológica Raso da Catarina, 28.VII.2009, fl., A.S. Conceição 1776 (HUNEB); 28.VII.2009, fl., A.S. Conceição 1792 (HUNEB); Trilha dos Quelés, 22.IX.2010, fl., D.D. Vieira 97 (HUNEB).

Material adicional: BRASIL. BAHIA: Cícero Dantas, 28.V.1981, fl., R.P. Orlandi 412 (ALCB). Euclides da Cunha, Sítio do Jaime, 21.IV.2004, fl., M.L. Guedes et al. 11467 (ALCB). Jeremoabo, estrada entre Jeremoabo e Canudos, 27.VI.2007, fl., R.M. Santos et al. 1668 (HUEFS); Fazenda Natureza, 12.VIII.2005, fl., E.B. Miranda et al. 887 (HUEFS). Muro, 18.X.2009, fl., E. Melo et al. 6738 (HUEFS). Monte Santo, 21.I.2006, fr., M.L. Guedes 12073 (ALCB). Pilão Arcado, 01.III.2000, fl., G. Cavalcanti 33 (ALCB). Ribeira Pombal, 15.X.2003, fl., M.L. Guedes 10507 (ALCB).

Cordia trichotoma possui grande amplitude ecológica, podendo ser encontrada nas Regiões Nordeste, Centro-oeste, Sudeste e Sul, em vegetação de cerrado, matas de galeria e em caatinga (Taroda \& Gibbs 1987). Ocorre do Ceará até o Rio Grande do Sul, no Nordeste da Argentina, no Leste do Paraguai e Bolívia (Maia 2004). Na área de estudo, foi coletada com flores em julho e setembro, em solo arenoso e areno-argiloso, próximo a encostas de morros. Caracteriza-se, principalmente, por apresentar inflorescências paniculiformes, densas e vistosas, portando flores com ca. 1,9 cm, com aroma desagradável, cálice tubular costado, corola hipocrateriforme com lobos subtruncados, e principalmente pela presença de tricomas estrelados. 
2. Heliotropium L., Sp. pl. 1: 130. 1753.

Subarbustos ou ervas, anuais ou perenes, eretos a decumbentes, ramos escabrosos a estrigosos ou escabrosos a hirsutos. Folhas alternas, subopostas ou opostas, pecioladas, persistentes, margem inteira ou irregular. Inflorescências escorpioides, terminais, falsamente terminais e/ou axilares, laxas ou congestas. Flores andróginas, subsésseis ou sésseis; cálice parcialmente unido, com lacínios diferentes entre si, estrigosos a pubescentes; corola alva ou arroxeada, fauce amarela, tubular-salverforme ou obcampanulada, estrigosa ou híspida, principalmente na fauce, internamente pubescente a tomentosa ou híspida; lobos suborbiculares a orbiculares. Estames 5, subsésseis, epipétalos; anteras livres, introrsas. Ovário bilocular, algumas vezes tetralocular pela intrusão de um falso septo, óvulos 1 ou 2 por lóculo; estilete terminal; estigma inteiro, umbraculiforme ou clavado. Fruto esquizocarpo, duas núculas com duas sementes cada; cálice persistente e acrescente. Sementes oblongas a elípticas ou trígonas, embrião plano.

Heliotropium inclui aproximadamente 200 espécies, distribuídas nas regiões tropicais, subtropicais e temperadas, com centros de diversidade na região Turco-iraniana e América do Sul. No Brasil, ocorrem nove espécies e duas subespécies. Na vegetação de caatinga, ocorrem cinco espécies, comuns em outros ambientes (Diane et al. 2004; Melo \& Semir 2008; Melo et al. 2010).

2.1. Heliotropium angiospermum Murray, Prodr. stirp. götting.: 217. 1770. Figs. 2d, 4a-e

Subarbustos ou ervas de 10-60 cm; ramos fistulosos, escabrosos a estrigosos. Folhas alternas, subopostas a opostas; lâmina 2,2-9 × 1,3-4,4, membranácea, discolor, oval a elíptica, ápice agudo a acuminado, margem inteira, ciliada, base atenuada, face adaxial estrigosa, face abaxial estrigosa a pubescente, principalmente nas nervuras; pecíolo $0,4-1,8 \mathrm{~cm}$, sulcado, estrigoso a hirsuto; venação eucamptódroma. Inflorescência 1,2-16 cm, escorpioide, falsamente terminal e axilar, laxa a congesta, inteira ou bifurcada; pedúnculo 1-6 $\mathrm{cm}$, pubescente. Flores ca. 4 $\mathrm{mm}$, sésseis; cálice $2-3 \mathrm{~mm}$, verde, estrigoso a pubescente, lacínios $1,8-2,2 \times 0,3-0,5 \mathrm{~mm}$, elípticos a estreitamente elípticos; corola 3-4 $\mathrm{mm}$, obcampanulada, alva a arroxeada, fauce amarela, externamente estrigosa, internamente tomentosa, lobos 1,2-2 × 1-1,5 mm, orbiculares; estames 5, epipétalos, subsésseis, livres, anteras
1-1,4 mm, ovais; ovário ca. $0,5 \mathrm{~mm}$, subgloboso, disco nectarífero ausente; estigma $0,5-0,8 \mathrm{~mm}$, umbraculiforme, séssil. Esquizocarpo 2-3 mm compr. $\times$ ca. 2 mm diâm., depresso-globoso, verde, verruculoso. Sementes 4, ca. 1,5 compr. $\times$ ca. 0,6 mm diâm., oblongas a elípticas.

Material examinado: APA Serra Branca, Fazenda Serra Branca, 31.VII.2009, fl. e fr., A.S. Conceição 1862 (HUNEB). Povoado Quelés, sentido Estação Ecológica Raso da Catarina. 19.VI.2009, fl. e fr., A.S. Conceição 1743 (HUNEB).

Material adicional: BRASIL. BAHIA: Campo Formoso, 21.IV.1981, fl. e fr., W.N. Fonseca 380 (ALCB). Morro do Chapéu, 3.IV.2004, fl. e fr., M.L. Guedes et al. 11054 (ALCB). Paulo Afonso, Raso da Catarina, Baixio do Cachimbo, 10.VIII.2005, fl. e fr., E.B. Miranda et al. 858 (HUEFS). Riacho, 18.V.1981, fl. e fr., G. Pinto 125 (HRB). Tucano, Bizamum ca. $30 \mathrm{~km}$ de Tucano, 6.II.2004, fl. e fr., L.P. Queiroz et al. 9022 (HUEFS).

Heliotropium angiospermum ocorre desde o Sul dos Estados Unidos (Texas e Flórida) e América Central, incluindo Antilhas, até o Brasil, onde é encontrada em quase toda Região Nordeste (com exceção do estado do Maranhão), do litoral à caatinga, e na Região Sudeste, nos estados de Minas Gerais e Rio de Janeiro (Melo \& Semir 2008; Melo et al. 2010, 2012). Na APA, a espécie foi coletada com flores e frutos entre os meses de junho e setembro, encontrada em ambiente aberto, na borda de vegetação arbustiva, próximo a base dos troncos de árvores e residências, em solo areno-argilosos. Assemelha-se a H. elongatum por compartilharem inflorescências escorpioides, com corolas alvas a arroxeadas e fauce amarela. No entanto, $H$. angiospermum pode ser diferenciada de H. elongatum, por possuir ramos estrigosos a escabrosos ( $v s$. escabrosos a hirsutos), corola obcampanulada ( $v s$. tubular-salverforme), estigma umbraculiforme e fruto depresso-globoso de superfície verruculosa ( $v s$. estigma clavado e fruto mitriforme de superfície híspida).

2.2. Heliotropium elongatum (Lehm.) I.M.Johnst., Contr. Gray Herb. Harv. Univ. 81: 18. 1928.

Figs. $2 \mathrm{e}, 4 \mathrm{f}-\mathrm{i}$

Erva, ca. $70 \mathrm{~cm}$, ereta a decumbente; ramos angulosos, fistulosos, escabrosos a hirsutos. Folhas alternas, subopostas a opostas; lâmina 2,5-7 × 1-5 cm, membranácea, discolor, oval a romboide, ápice agudo a acuminado, margem irregular, base assimétrica a atenuada, face adaxial bulada, estrigosa, entremeada por tricomas maiores, ambos aciculiformes, face abaxial estrigosa a tomentosa; 


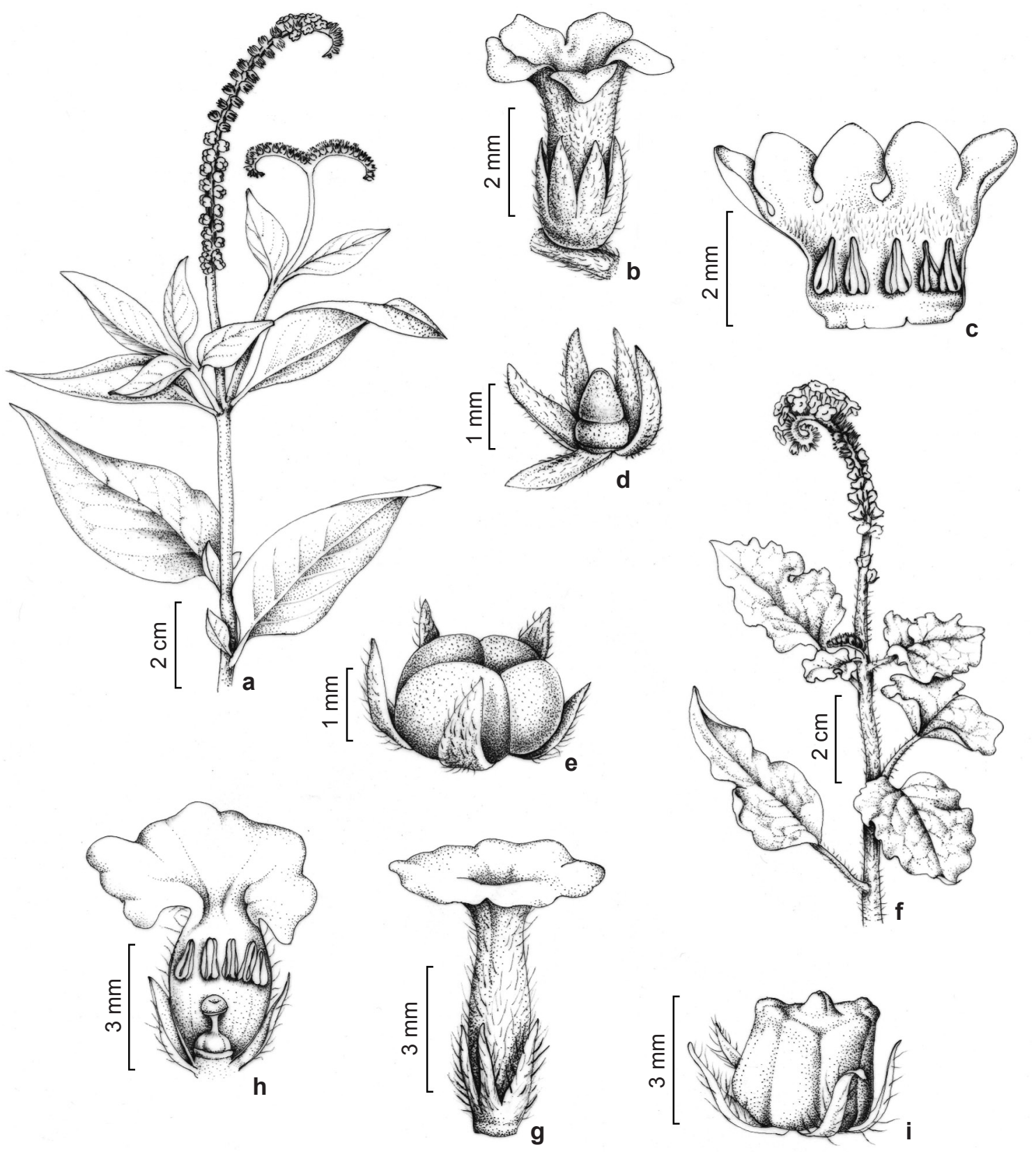

Figura 4 - a-e. Heliotropium angiospermum Murray - a. ramo reprodutivo; b. flor; c. seção longitudinal da flor, evidenciando androceu; d. gineceu; e. fruto (M.V.V. Romão 550). f-i. Heliotropium elongatum (Lehm.) I.M.Johnst. - f. ramo reprodutivo; g. flor; h. seção longitudinal da flor, evidenciando androceu e gineceu; i. fruto (D.D. Vieira 05). Figure 4 - a-e. Heliotropium angiospermum Murray - a. fertile branch; b. flower; c. longitudinal section of flower, showing androecium; d. gynoecium; e. fruit (M.V.V. Romão 550). f-i. Heliotropium elongatum (Lehm.) I.M.Johnst. - f. fertile branch; g. flower; h. longitudinal section of flower, showing androecium and gynoecium; i. fruit (D.D. Vieira 05).

pecíolo $0,7-2 \mathrm{~cm}$, parcialmente alado, hirsuto; venação eucamptódroma. Inflorescência 1,5-12,5 $\mathrm{cm}$, escorpioide, falsamente terminal e axilar, congesta; pedúnculo $1,4-4,5 \mathrm{~cm}$, hirsuto, eixo estrigoso a hirsuto. Flores 4-7 mm, sésseis; cálice
1,8-2,5 mm, verde, estrigoso, lacínios 1,5-2 $\times$ $0,2-0,4 \mathrm{~mm}$, estreitamente elípticos; corola 3,5-6,8 $\mathrm{mm}$, tubular-salverforme, alva ou roxa, fauce amarela, híspida, 1-1,2 × 1,5 mm, arredondados; estames 5, epipétalos, subsésseis, livres entre si, 
anteras ca. $1 \mathrm{~mm}$, oblongas a lanceoladas; ovário ca. 0,5 mm, subgloboso, disco nectarífero ca. 0,1 $\mathrm{mm}$; estilete ca. $0,5 \mathrm{~mm}$, estigma ca. $0,4 \mathrm{~mm}$, clavado. Esquizocarpo 3,5-4,5 mm compr. $\times 2,5-4$ mm diâm., mitriforme, verde, híspido; núculas costadas, híspidas. Sementes 2 por núcula, ca. 3,5 mm compr. $\times$ ca. $1 \mathrm{~mm}$ diâm., trígonas.

Material examinado: Serra Branca, Estrada dos Quelés, 8.XII.2009, fl. e fr., T.M.S. Melo 118 (HUNEB); 22.IX.2010, fl. e fr., D.D. Vieira 100 (HUNEB).

Material adicional: BRASIL. BAHIA: Canudos, Reserva Biológica de Canudos, 5.I.2002, fl. e fr., M.S. Castro 66335 (ALCB); 20.III.2003, fl. e fr., F.H.M. Silva 413 (HUEFS). Cruz das Almas, 2.XI.2000, fl., A.C.C. Rodrigues 10 (ALCB). Irecê, Barragem de São Bento, 25.X.2009, fl. e fr., M.L. Guedes 16094 (ALCB). Paulo Afonso, Estação Ecológica Raso da Catarina, 30.XI.2005, fl. e fr., F. França et al. 5324 (HUEFS). Rodelas, 22.I.1987, fl. e fr., G.O. Mattos 35 (ALCB).

Esta espécie é endêmica da América do Sul, ocorrendo na Bolívia, Brasil, Uruguai, Argentina e Paraguai (Johnston 1928). No Brasil é encontrada em toda a Região Nordeste e nos estados do Pará, Tocantins, Mato Grosso, Goiás, Mato Grosso do Sul, Minas Gerais, Rio de Janeiro, São Paulo, Paraná, Santa Catarina e Rio Grande do Sul (Melo et al. 2012). Na APA foi encontrada com flores e frutos em setembro e dezembro, em ambientes abertos com solo arenoso, próximo à vegetação arbustivo-arbórea, na base de cercas e quintais. Heliotropium elongatum pode ser reconhecida por apresentar lâmina foliar bulada na face adaxial, estigma clavado e, principalmente, pelo fruto mitriforme com núculas justapostas.

\section{Tournefortia L., Sp. pl. 1: 140. 1753.}

Arbustos, eretos ou escandentes, ramos glabros, vilosos ou estrigosos, lenticelados. Folhas alternas, pecioladas, persistentes, margem inteira. Inflorescências escorpioides, terminais ou axilares, laxas. Flores andróginas, sésseis; cálice parcialmente unido, com lacínios levemente desiguais entre si, glabros a estrigosos; corola verde ou alaranjada, tubular, serícea, internamente glabra a pubescente; lobos lineares, involutos. Estames sésseis, epipétalos; anteras coerentes pelo ápice, introrsas. Ovário bilocular, algumas vezes tetralocular pela intrusão de um falso septo, óvulos 2 por lóculo; estilete terminal; estigma inteiro, cônico ou subpeltado. Fruto drupáceo, 4 pirênios; cálice persistente. Sementes 4, suborbiculares ou depressoglobosas, embrião curvo.
Tournefortia engloba cerca de 150 espécies distribuídas nas regiões tropicais, subtropicais e temperadas. No Brasil ocorrem 19 espécies, dentre as quais sete ocorrem na caatinga (Melo \& Sales 2005; Melo et al. 2010, 2012).

3.1. Tournefortia rubicunda Salzm. ex DC., Prodr. 9: 526.1845.

Figs. 2f, 5a-f

Arbusto 1,5-1,7 m; ramos enegrecidos, glabros ou estrigosos, lenticelas esbranquiçadas. Folhas alternas; lâmina 2,5-10,5 × 0,8-4 cm, membranácea, discolor, oval a lanceolada, ápice agudo a acuminado, margem inteira, ciliada, base obliqua, estrigosa em ambas as faces, tricomas com base acentuadamente discoide; pecíolo 0,3-1,1 cm, estrigoso; venação eucamptódroma. Inflorescência 2-5,8 cm, escorpioide, terminal e axilar, laxa; pedúnculo 0,7-1,5 cm, estrigoso. Flores ca. $5 \mathrm{~mm}$, sésseis, cálice ca. 2-2,5 mm, verde, estrigoso, lacínios $1,8-2,2 \times 0,2-0,3 \mathrm{~mm}$, lanceolados, com tamanhos desiguais entre si, dois maiores e três menores; corola 3-4 mm, tubular, constricta na metade inferior do tubo, verde a alaranjada, externamente serícea, internamente glabra, lobos $2-2,3 \times 0,1-0,2 \mathrm{~mm}$, lineares, involutos; estames 5 , epipétalos, sésseis, anteras 0,6-1 mm, ovais a lanceoladas, ápice apiculado, coerentes pelo ápice; ovário ca. $1 \mathrm{~mm}$, obclavado, disco nectarífero ca. 0,2 $\mathrm{mm}$; estilete 1,5-2 $\mathrm{mm}$, estigma ca. $0,5 \mathrm{~mm}$, subpeltado, bífido no ápice, pubescente. Fruto drupáceo ca. 5 mm compr. × 2-3 mm diâm., subgloboso, verde quando jovem, alaranjado quando maduro, glabro a hirsuto. Sementes 4, ca. 2,5 mm compr. $\times 1,5$ mm diâm., lisas, suborbiculares.

Material examinado: Fazenda Serra Branca, Baixão da Serra Branca, 18.IV.2008, fl e fr., A.S. Conceição 1352 (HUNEB); Trilha do Araçá, 8.V.2008, fl. e fr., M.V.V. Romão 115 (HUNEB); Vaca Morta, 16.IV.2008, fr., M.V.V. Romão 47 (HUNEB); 17.IV.2008, fr., A.S. Conceição 1280 (HUNEB).

Material adicional: BRASIL. BAHIA: Glória, Aldeia Serrota, 26.IV.2006, fl., M. Colaço et al. 117 (HUEFS); Brejo do Burgo, 3.VII.1995, fl. e fr., F.P. Bandeira 231 (HRB). Jeremoabo, Raso da Catarina, 15.V.1981, fr., G. Pinto 105 (HRB). Monte Santo, 12.I.2006, fr., M.L. Guedes et al. 12157 (ALCB). Paulo Afonso, Reserva Ecológica Raso da Catarina, 26.VI.1982, fl. e fr., M.L. Guedes et al. 508 (ALCB). Quixaba, caminho para Itupiara, a 43 km, 25.VI.2001, fr., M.L. Guedes et al. 7923 (ALCB). Santa Brígida, Raso da Catarina, 28.VI.2002, fl., L.P. Queiroz 7588 (HUEFS). Tucano, Serra do Pai Miguel, 4.I.2006, fl. e fr., D. Cardoso 899 (HRB). Sítio do Mandacaru, 15.IV.2006, fl. e fr., $D$. Cardoso \& M. Guerreiro 1195 (HUEFS). 


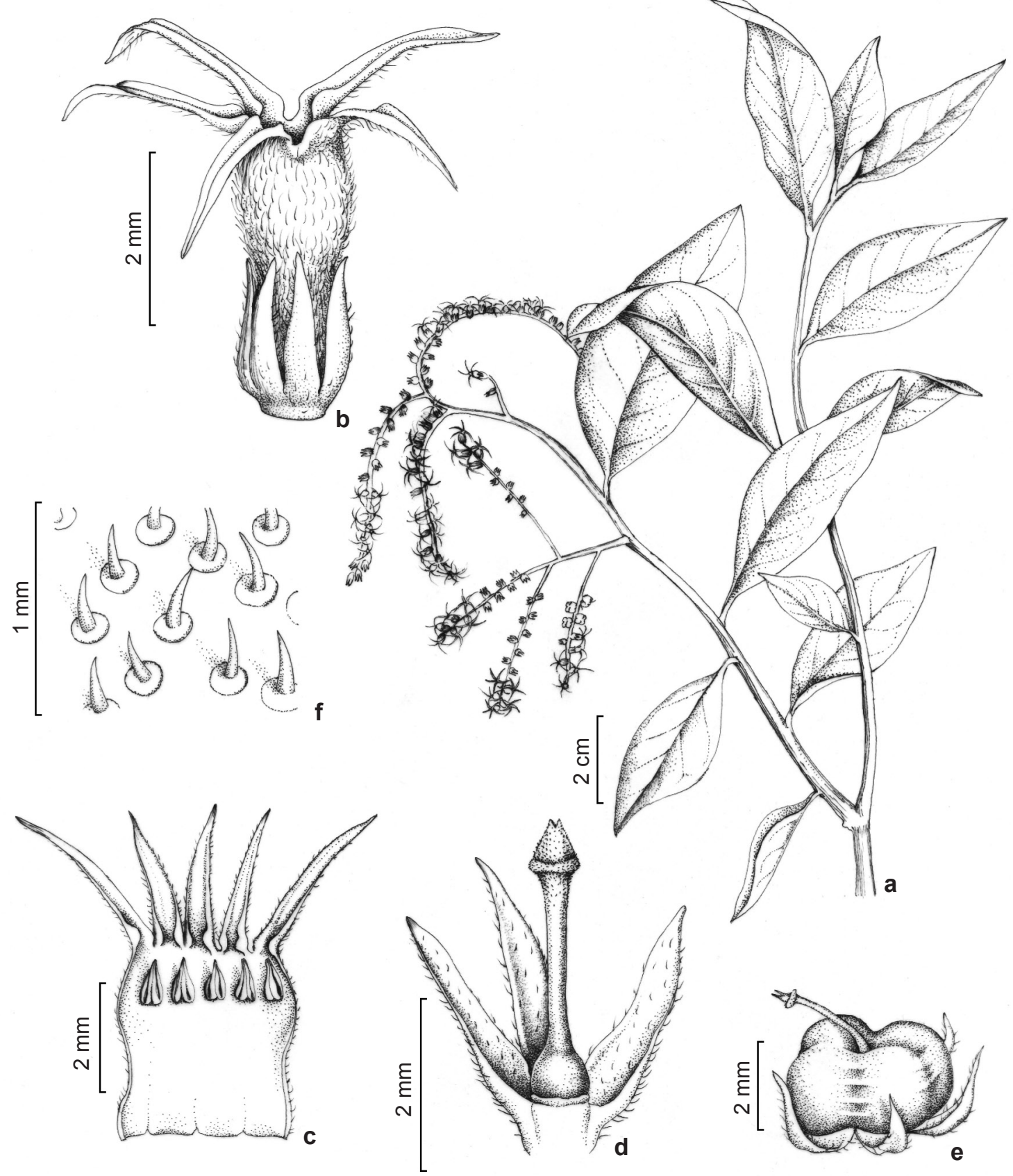

Figura 5 - a-f. Tournefortia rubicunda Salzm. ex DC. - a. ramo reprodutivo; b. flor; c. seção longitudinal da flor, evidenciando androceu; d. gineceu; e. fruto; f. tricomas com base discóide, face adaxial da folha (A.S. Conceição 1352). Figure 5 - a-f. Tournefortia rubicunda Salzm. ex DC. - a. fertile branch; b. flower; c. longitudinal section of flower, showing androecium; d. gynoecium; e. fruto; f. trichomes based discoid, upper surface leaf (A.S. Conceição 1352).

Na América do Sul, a espécie distribui-se no Brasil, Bolívia, Paraguai e Norte da Argentina (Johnston 1930). No Brasil, ocorre em ambientes de caatinga, cerrado e mata, nos estados do Amazonas, Paraíba, Pernambuco, Bahia, Alagoas,
Goiás, Distrito Federal, Mato Grosso do Sul, Minas Gerais, Espírito Santo, São Paulo, Rio de Janeiro e Paraná (Melo et al. 2010). Na área de estudo, está associada à vegetação arbustivoarbórea, florescendo e frutificando nos meses de 
abril e maio. Pode ser facilmente reconhecida pelo hábito arbustivo, formando touceiras, folhas ovais a lanceoladas apresentando tricomas com base acentuadamente discoide, ovário obclavado e estigma subpeltado.

\subsection{Tournefortia salzmannii DC., Prodr. 9: 524.} 1845.

Fig. 6a-f

Arbusto escandente 1,8-3 m; ramos glabros ou vilosos, lenticelas amarronzadas. Folhas alternas; lâmina 2,2-5,5 × 1,5-2,6 cm, membranácea, discolor, elíptica a oval, ápice agudo a obtuso, margem inteira, ciliada, base arredondada, face adaxial estrigosa, face abaxial vilosa a tomentosa, tricomas com base nunca discoide; pecíolo $0,3-1,0$ $\mathrm{cm}$, viloso; venação broquidódroma. Inflorescência 3,5-5 cm, escorpioide, terminal, laxa; pedúnculo 0,5-2 cm, viloso a tomentoso. Flores ca. $5 \mathrm{~mm}$, sésseis, cálice $2-2,5 \mathrm{~mm}$, verde, externamente viloso e internamente glabro, lacínios 1,5-2 $\times$ $0,2-0,4 \mathrm{~mm}$, lanceolados, levemente desiguais entre si; corola 3-4 mm, tubular, constricta na metade inferior do tubo, verde, externamente serícea, internamente pubescente, lobos 1,8-2 $\times 0,1-0,2 \mathrm{~mm}$, lineares, involutos, punctados; estames 5 , epipétalos, sésseis, anteras $0,5-0,8 \mathrm{~mm}$, ovais a lanceoladas, ápice agudo, coerentes pelo ápice; ovário ca. $1 \mathrm{~mm}$, cônico-piramidal, disco nectarífero ca. $0,2 \mathrm{~mm}$; estilete ca. $1,5 \mathrm{~mm}$, estigma ca. $0,5 \mathrm{~mm}$, estreitamente cônico, pubescente. Fruto drupáceo $3 \mathrm{~mm}$ compr. $\times 3 \mathrm{~mm}$ diâm., globoso, verde-claro quando jovem, verde quando maduro, glabrescente. Sementes 4 , ca. $2 \mathrm{~mm}$ compr. $\times$ 1,5 mm diâm., verruculosas, depresso-globosas, ventralmente fendidas.

Material examinado: Fazenda Serra Branca, Estrada saindo de Quelés, sentido Estação Ecológica Raso da Catarina, estrada secundária a direita, 5.V.2011, fl. e fr., D.D. Vieira 151 (HUNEB); 17.VI.2011, fr., R.R. Varjão 130 (HUNEB).

Tournefortia salzmannii distribui-se desde o Paraguai, Bolívia e Argentina, alcançando o Brasil (Johnston 1930), onde é encontrada do Piaú ao Rio de Janeiro associada aos ambientes de caatinga, cerrado e mata atlântica (Melo et al. 2010, 2012). $\mathrm{Na}$ área de estudo, está associada a ambientes de transição entre caatinga e mata. Encontrada com flores e frutos em maio e com frutos em junho. Tournefortia salzmannii diferencia-se de T. rubicunda pela presença da lâmina foliar elíptica a oval, ovário cônico-piramidal e estigma estreitamente cônico.
4. Varronia P. Browne, Civ. Nat. Hist. Jamaica: 172. 1756.

Arbustos ou subarbustos, geralmente multiramificados; ramos estrigosos, hirsutos ou velutinos, com tricomas simples, lenticelados. Folhas alternas, dísticas ou espiraladas, pecioladas ou sésseis, persistentes, margem serreada. Inflorescências espiciformes ou glomérulo-globosas, terminais e internodais, congestas. Flores andróginas ou funcionalmente unissexuais, sésseis; cálice gamossépalo, geralmente campanulado, às vezes com apêndices lineares apicais, glabros, puberulentos, estrigosos a hirsutos; corola alva, infundibuliforme a salverforme, glabra, lobos ovais a lanceolados, truncados ou suborbiculares. Estames 5, com filetes desenvolvidos, epipétalos; anteras livres, introrsas ou extrorsas. Ovário tetralocular, óvulos 4; estilete 2 vezes bifurcado; ramos estigmáticos 4 , clavados ou foliáceos. Fruto drupa, mucilaginoso, cálice persistente e acrescente. Semente 1, cônica ou ovoide, embrião plano.

Varronia possui aproximadamente 100 espécies, distribuídas nos trópicos do Novo Mundo e regiões áridas do Arizona à Argentina. No Brasil, ocorrem 27 espécies, sete delas associadas à vegetação de caatinga (Miller \& Gottschling 2007; Melo et al. 2010). O caráter heterostilia (distilia e tristilia) é comum em espécies do gênero Varronia, podendo ser verificado a depender do número de indivíduos analisados. Nos espécimes estudados, o caráter não foi observado.

4.1. Varronia curassavica Jacq., Enum. Syst. Pl.:14. 1760. Figs. 2g, 7a-d

Arbusto 1,5-3,5 m, escandente a subescandente; ramos estrigosos a hirsutos, lenticelas amarronzadas. Folhas alternas; lâmina 1,5-8,5 $\times 0,5-3 \mathrm{~cm}$, membranácea a cartácea, discolor, lanceolada, oval-lanceolada a oblongo-lanceolada, ápice agudo, margem serreada, base atenuada, face adaxial estrigosa, ocasionalmente puberulenta, face abaxial pubescente a tomentosa; pecíolo 3-7 $\mathrm{mm}$, tomentoso; venação semicraspedódroma. Inflorescência 1,7-10,5 cm, espiciforme, terminal e internodal, congesta; pedúnculo $1-6 \mathrm{~cm}$, estrigoso, eixo estrigoso a hirsuto. Flores 4-7 mm, sésseis; cálice 2-4 mm, campanulado, creme a verdeclaro, externamente hirsuto, internamente glabro; lacínios 1,5-3 × 1-2 mm, trulados; corola 3-6 mm, infundibuliforme a salverforme, alva, glabra; lobos $2-2,5 \times 1,5-2 \mathrm{~mm}$, ovais a lanceolados; estames 5 , epipétalos, pilosos, filetes $1-1,5 \mathrm{~mm}$, anteras 0,8-1 mm, orbiculares a truladas; ovário ca. $1 \mathrm{~mm}$, 


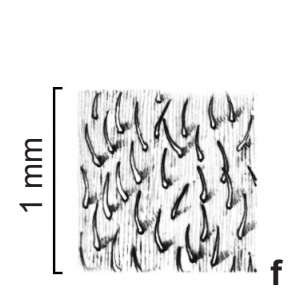

\section{,}
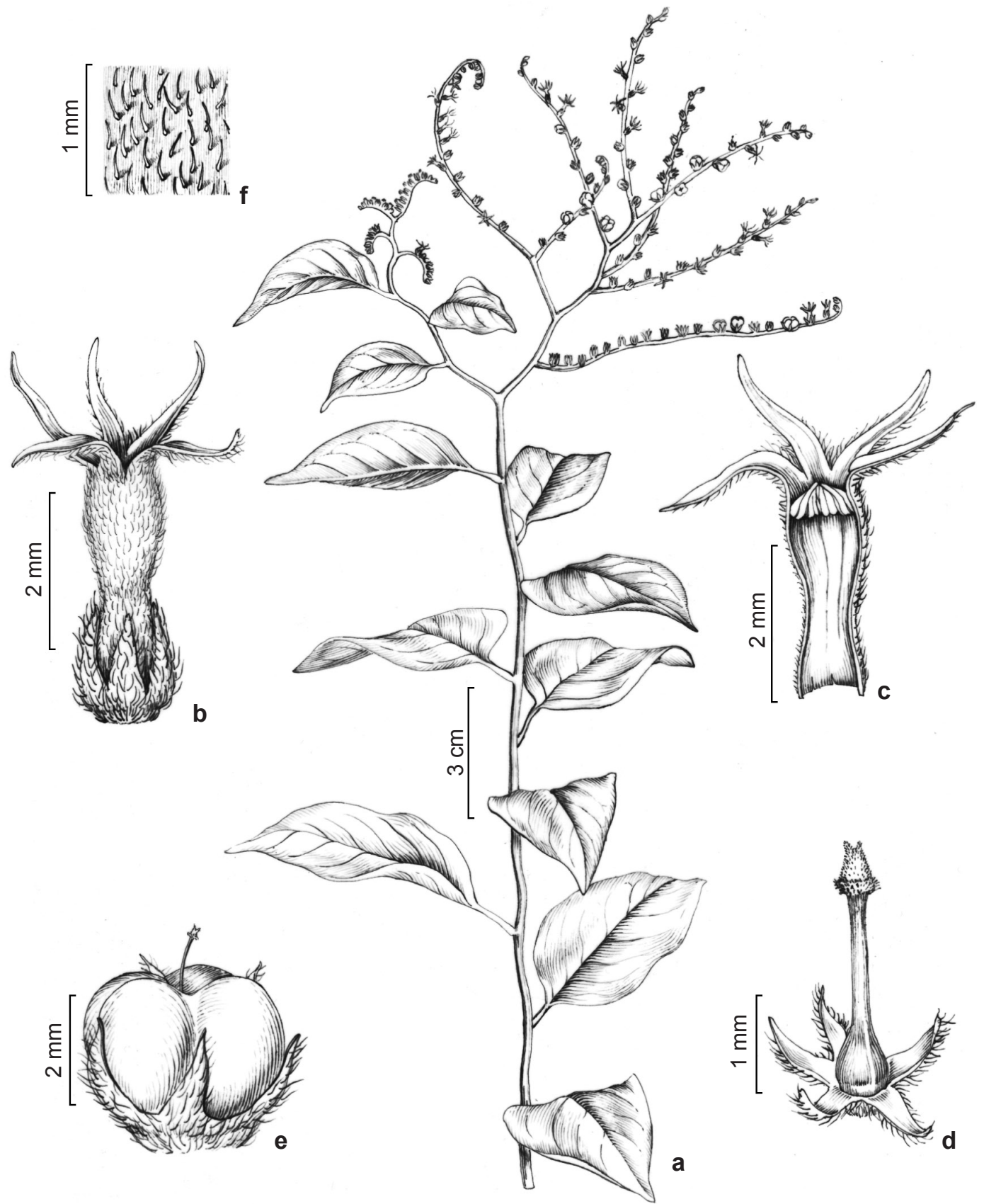

Figura 6 - a-f. Tournefortia salzmannii DC. - a. ramo reprodutivo; b. flor; c. corte longitudinal da flor, evidenciando androceu; d. gineceu; e. fruto; f. tricomas simples, face adaxial da folha (D.D. Vieira 151).

Figure 6 - a-f. Tournefortia salzmannii DC. - a. fertile branch; b. flower; c. longitudinal cut flower, showing androecium; d. gynoecium; e. fruto; f. simple trichomes, upper surface leaf (D.D. Vieira 151).

subgloboso, disco nectarífero ca. $0,2 \mathrm{~mm}$; estilete ca. 0,9 mm nas flores brevistilas, 2-4 mm nas flores longistilas, estigmas $0,5-0,8 \mathrm{~mm}$, clavados. Drupa ca. $5 \mathrm{~mm}$ compr., $\times$ ca. $3 \mathrm{~mm}$ diâm., ovoide, imatura verde, matura vermelha, cálice persistente. Semente 1, ca. 3,5 mm compr. $\times$ ca. 2,5 mm diâm., cônica.
Material examinado: APA Serra Branca, Limite da Estação Ecológica Raso da Catarina, 17.VI.2009, fl. e fr., A.S. Conceição 1667 (HUNEB); Trilha do Logadouro, 19.VI.2009, fl., A.S. Conceição 1729 (HUNEB); Trilha dos Quelés, sentido Estação Ecológica Raso da Catarina, 19.VI.2009, fl. e fr., A.S. Conceição 1756 (HUNEB); 
9.XII.2009, fl. e fr., M.V.V. Romão 558 (HUNEB); 22.IX.2010, fl., D.D. Vieira 96 (HUNEB); Vaca Morta, 16.IV.2008, fr., M.V.V. Romão 68 (HUNEB); 12.III.2008, fl., A.S. Conceição 1218 (HUNEB); 17.IV.2008, fl. e fr., A.S. Conceição 1294 (HUNEB).

Material adicional: BRASIL. BAHIA: Campo Formoso, Poços, 13.IV.2006, fl., R.P. Souza et al. 42 (HUEFS). Cruz das Almas, próximo ao Povoado Sapucaia, 3.XI.2000, fl. e fr., A.C.C. Rodrigues 17 (ALCB). Euclides da Cunha, 20.III.2004, fr., M.L. Guedes et al. 10887 (ALCB). Jacobina, Caminho para Pingadeira, 6.IV.1996, fl. e fr., M.L. Guedes 2849 (HRB). Jequié, Barragem da Pedra, 19.X.1997, fl. e fr., M.L. Guedes 5417 (ALCB). Jeremoabo, Baixa dos Quelés, 17.X.2009, fl., E. Melo et al. 6693 (HUEFS).Muro, 18.X.2009, fl., E. Melo et al. 6771 (HUEFS); Milagres, 15.IV.1995, fl. e fr., E. Melo \& F. França 1203 (HUEFS). Rodelas, 21.I.1987, fl., L.B. Silva \& G.O. Matos e Silva 47 (HRB). Serrinha, beira da estrada, 19.III.2005, fl., S.F. Conceição 121 (HUEFS).

A espécie distribui-se do sudeste do México, alcançando o Panamá, Antilhas até o Nordeste da América do Sul (Gibson 1970). No Brasil, está amplamente distribuída em todas as regiões, sendo encontrada em diversas formações vegetacionais (Melo \& Sales 2005; Melo et al. 2010). Na área de estudo, foi coletada em vegetação arbustivo-arbórea sobre solo arenoso e pedregoso, com flores e frutos nos meses de abril, junho, setembro e dezembro. A espécie apresenta hábito arbustivo, escandente a subescandente, podendo ser reconhecida, sobretudo pelas folhas lanceoladas, de base atenuada, associada às flores reunidas em inflorescências espiciformes com corola infundibuliforme a salverforme e ovário subgloboso.

4.2. Varronia globosa Jacq., Enum. Syst. P1.: 14. 1760 .

Figs. 2h, 7e-h

Arbusto, 1,5-3,5 m, ereto; ramos estrigosos a escabrosos, lenticelas esbranquiçadas. Folhas alternas; lâmina 1,5-4,2 ×0,5-2 cm, membranácea, discolor, lanceolada, oval a lanceolada, base cuneada a truncada, ápice agudo, margem serreada, face adaxial estrigosa a escabrosa, face abaxial escabrosa ou tomentosa, pecíolo $0,2-0,8 \mathrm{~mm}$, estrigoso a hirsuto; venação semicraspedódroma. Inflorescência 0,5-1 cm, glomérulo-globosa, terminal e internodal, congesta; pedúnculo 0,5-5 $\mathrm{cm}$, escabroso a hirsuto. Flores 3-7 mm, sésseis; cálice 3-3,5 mm, campanulado, verde, externamente estrigoso a hirsuto, internamente glabro, lacínios 1-1,2 × $1 \mathrm{~mm}$, obovais, ápice filiforme; corola 2,5-5 $\mathrm{mm}$, infundibuliforme, alva, glabra, lobos 1-2 $\times$ 1-1,5 mm, truncados; estames 5, epipétalos, livres, pilosos na base, filetes $1,5-2 \mathrm{~mm}$, anteras $0,6-1 \mathrm{~mm}$, oblongas a lanceoladas; ovário ca. 1,5 mm, piriforme, disco nectarífero $0,8-1 \mathrm{~mm}$; estilete ca. 1,2 nas flores brevistilas, 2,4-3,5 mm nas flores longistilas, estigmas 0,5-0,8 mm, clavados. Drupa ca. 3,5 mm compr. $\times 1,5-2 \mathrm{~mm}$ diâm., globosa, vermelha na maturidade, glabra, cálice persistente. Semente 1, ca. 3 mm compr. $\times$ ca. 1,5 mm diâm, cônica a ovoide.

Material examinado: APA Serra Branca, Fazenda Serra Branca, Baixão da Serra Branca, 18.IV.2008, fl. e fr., A.S. Conceição 1322 (HUNEB); Estrada próxima a Serra do Navio, 4.XI.2010, fl., R.R. Varjão 07 (HUNEB). Povoado Quelés, sentido Estação Ecológica Raso da Catarina, 16.VI.2009, fl., A.S. Conceição 1747 (HUNEB); Tanque de Dentro, 30.X.2008, fl. e fr., M.V.V. Romão 391 (HUNEB); Vaca Morta, 16.IV.2008, fl., M.V.V. Romão 71 (HUNEB).

Material adicional: BRASIL. BAHIA: Barra dos Mendes, 16.XII.2009, fl., E. Melo 7586 (ALCB). Canudos, Estação Biológica de Canudos, 27.VI.2002, fl., L.P. Queiroz et al. 7215 (HUEFS); 16.II.2003, fl., F.H.M. Silva 33 (HUEFS); 17.II.2004, fl. e fr., R.M. Harley 54861 (HUEFS). Itiúba, Fazenda Experimental da EPABA, 26.V.1983, fl., H.P. Bautista \& G.C. Pinto 750 (HRB). Jeremoabo, estrada entre Jeremoabo e Canudos, 27.VI.2007, fl., R.M. Santos 1653 (HUEFS). Monte Santo, 11.I.2006, fl. e fr., M.L. Guedes 12075 (ALCB). Paulo Afonso, Aldeia Serrota, 26.IV.2006, fl., M. Colaço 114 (HUEFS); 6.VI.2006, fl., M. Colaço 135 (HUEFS). Tucano, Distrito de Caldas do Jorro, 2.III.1992, fl. e fr., A.M. Carvalho \& D.J.N. Hind 3885 (HRB). Bizamum, ca. $30 \mathrm{~km}$ de Tucano, 6.II.2004, fl., L.P. Queiroz 9013 (HUEFS).

Varronia globosa distribui-se desde o Sul dos Estados Unidos (Flórida), México e América Central, inclusive nas Antilhas, alcançando a Venezuela e o Nordeste da América do Sul (Nowicke 1969; Miller 1988). No Brasil, ocorre exclusivamente na vegetação de caatinga do Ceará a Bahia (Taroda 1984; Melo et al. 2010, 2012). $\mathrm{Na}$ área de estudo, a espécie foi encontrada em vegetação arbustiva, associada aos solos arenosos, argilosos e pedregosos, coletada com flores nos meses de abril, outubro e novembro. O hábito arbustivo, inflorescências glomérulo-globosas, cálice campanulado e corola infundibuliforme são caracteres compartilhados com $V$. leucocephala (Moric.) J.S.Mill. Contudo, Varronia globosa apresenta hábito arbustivo bastante ramificado, cálice com lacínios de ápices filiformes e corola de 2,5-5 mm, diferindo de $V$. leucocephala, que possui hábito subarbusto ou arbusto pouco ramificado, cálice com lacínios de ápices agudos e corola com 2,5-3,5 cm. 


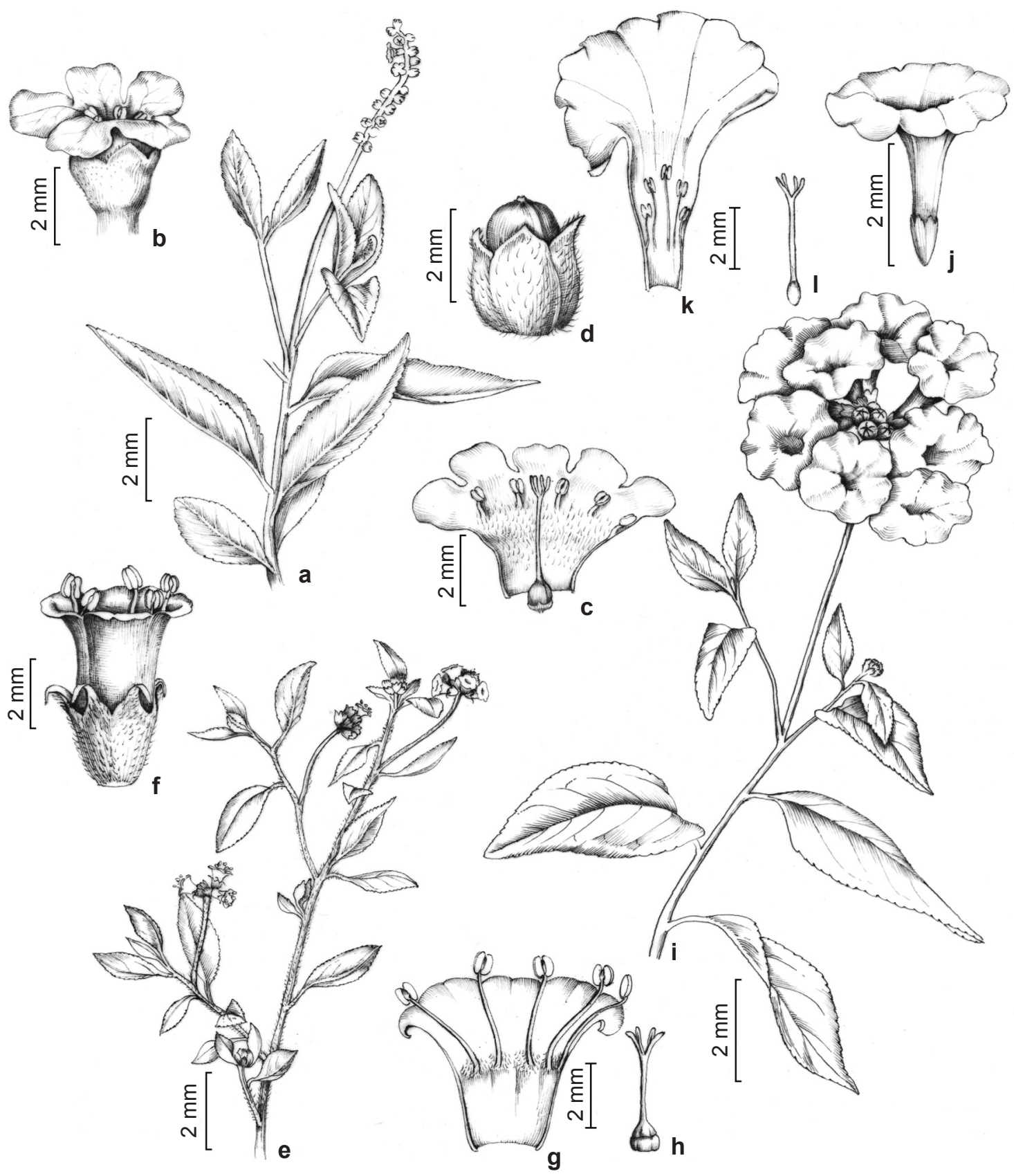

Figura 7 - a-d. Varronia curassavica Jacq. - a. ramo florífero; b. flor; c. seção longitudinal da flor, evidenciando androceu e gineceu; d. fruto (A.S. Conceição 246). e-h. Varronia globosa Jacq. - e. ramo florífero; f. flor; g. seção longitudinal da flor, evidenciando androceu; h. gineceu (R.R. Varjão 07). i-1. Varronia leucocephala (Moric.) J.S.Mill.i. ramo florífero; j. flor; k. seção longitudinal da flor, evidenciando androceu; 1. gineceu (A.S. Conceição 1295).

Figure 7 - a-d. Varronia curassavica Jacq. - a. fertile branch; b. flower; c. longitudinal section of flower, showing androecium and gynoecium; d. fruit (A.S. Conceição 246). e-h. Varronia globosa Jacq. - e. fertile branch; f. flower; g. longitudinal section of flower, showing androecium; h. gynoecium (R.R. Varjão 07). i-l. Varronia leucocephala (Moric.) J.S.Mill. - i. fertile branch; j. flower; k. longitudinal section of flower, showing androecium; 1. gynoecium (A.S. Conceição 1295). 
4.3. Varronia leucocephala (Moric.) J.S.Mill., Novon 17(3): 374. 2007.

Figs. 2i, 7i-1

Arbusto ou subarbusto, ereto, 1-2,5 m; ramos velutinos, entremeados por indumento híspido, lenticelas esbranquiçadas. Folhas alternas dísticas; lâmina 3-9 × 1,1-4,5 cm, membranácea, discolor, oval, elíptica a lanceolada, ápice agudo, margem serreada, base cuneada a obtusa, face adaxial estrigosa, face abaxial pubescente a tomentosa; pecíolo $0,2-1,8 \mathrm{~cm}$, estrigoso; venação craspedódroma. Inflorescência $5,2-8 \mathrm{~cm}$, glomérulo-globosa, terminal, congesta; pedúnculo 3-11 cm, velutino, tricomas híspidos esparsamente distribuídos. Flores 2,5-4 cm, sésseis; cálice 4-8 mm, campanulado, verde, externamente puberulento, internamente glabro, lacínios 1,5-2 $\times 0,8-1 \mathrm{~mm}$, denteados, ápice agudo, estrigilosos; corola 2,5-3,5 cm, infundibuliforme, alva, glabra, lobos suborbiculares; estames 5, epipétalos, livres, pilosos na base; filete $0,5-2 \mathrm{~mm}$, anteras ca. $2 \mathrm{~mm}$, oblongas; ovário ca. $2 \mathrm{~mm}$, subgloboso, disco nectarífero ausente; estilete ca. $1,2 \mathrm{~cm}$, estigmas 0,8-1 mm, foliáceos. Drupa não observada.

Material examinado: Fazenda Serra Branca, Vaca Morta, 23.VIII.2008, fl., M.V.V. Romão 298 (HUNEB); 17.IV.2008, fl., A.S. Conceição 1295 (HUNEB).

Material adicional: BRASIL. BAHIA: Campo Formoso, estrada a Quixaba, 30.III.2004, fl., M.N.S. Stapf 266 (HUEFS). Canudos, 19.II.2004, fl., R.M. Harley 54906 (HUEFS); ca. 35,7 km de Canudos, 28.VI.2002, fl., L.P. Queiroz 7268 (HUEFS). Euclides da Cunha, 20.IV.2004, fl., M.L. Guedes et al. 108914 (HRB). Glória, Brejo do Burgo, 2.VII.1995, fl., F.P Bandeira 204 (HUEFS).Raso da Catarina, 5.VI.2004, fl., M.V.M. Oliveira 693 (HUEFS). Serra do Cágado, 11.I.1993, fl., F.P. Bandeira 112 (ALCB). Monte Santo, 11.I.2006, fl., M.L. Guedes et al. 12074 (ALCB). Paulo Afonso, acesso próximo a casa $\mathrm{n}^{\circ} 1$ do Raso da Catarina, 20.VI.1981, fl., M.L. Guedes et al. 298 (ALCB); Reserva Ecológica Raso da Catarina, 25.VI.1982, fl., L.P. Queiroz \& M.L. Guedes 369/487 (ALCB). Rodelas, Salgado do Melão, 3.VIII.1994, fl., M.C. Ferreira 603 (HRB). Santa Brígida, 24.V.1984, fl., L.C. Oliveira-Filho 177 (ALCB).

Varronia leucocephala é uma espécie restrita à vegetação de caatinga dos estados do Piauí, Ceará, Paraíba, Pernambuco e Bahia (Taroda \& Gibbs 1986b; Melo et al. 2010). Na área de estudo esta associada à caatinga arbustiva e arbustivo-arbórea, em solos arenosos, encontrada com flores nos meses de abril e agosto. Na área de estudo esta espécie pode ser confundida com $V$. globosa. No entanto, a espécie pode ser reconhecida, sobretudo, pelas flores apresentando cálice com lacínios de ápice agudo e corola com 2,5-3,5 cm.

\section{Agradecimentos}

À Fundação de Amparo à Pesquisa do Estado da Bahia (FAPESB), o apoio financeiro ao projeto (PET 0023/2007). À Companhia Hidro Elétrica do São Francisco (CHESF), o suporte nos trabalhos de campo. Aos assessores ad hoc as valiosas sugestões. O primeiro autor agradece também à FAPESB, a concessão de bolsa de Iniciação Científica (BOL 1768/2009); à professora Dr. ${ }^{a}$ Adilva de Souza Conceição, a orientação e oportunidades concedidas; ao Dr. José Iranildo Miranda de Melo e a Dr. ${ }^{a}$ María Natividad Sánchez de Stapf, os valiosos esclarecimentos sobre Boraginaceae. Aos curadores e técnicos dos herbários visitados, a prontidão durante a consulta das coleções. Ao Natanael Santos, as ilustrações botânicas.

\section{Referências}

Al-Shehbaz, I.A. 1991. The genera of Boraginaceae in the Southeastern United States. Journal of the Arnold Arboretum 1: 1-169.

Böhle, U.R. \& Hilger, H.H. 1997. Chloroplast DNA systematics of "Boraginaceae" and related families: a goodbye to the old familiar concept of 5 subfamilies. In: Smets, E.; Ronse Decraene, L.P. \& Robbrecht, E. (eds.). Programme \& Abstracts, Scripta Botanica Belgica Vol. 15. Pp. 30.

Borhidi, A.; Gondár, E. \& Orosz-Kovács, Zs. 1988. The reconsideration of the genus Cordia. Acta Botanica Hungarica 34: 375-423.

Cavalheiro, L.; Peralta, D.F. \& Furlan, A. 2003. Flórula fanerogâmica da planície litorânea de Picinguaba, Ubatuba, SP, Brasil: Boraginaceae. Hoehnea 30: 173-179.

Cavalheiro, L.; Ranga, N.T. \& Furlan, A. 2011. Tournefortia L. (Boraginaceae): espécies do Brasil extra-amazônico. Hoehnea 38: 221-242.

Diane, N.; Förther, H.; Hilger H.H. \& Weigend, M. 2004. Heliotropiaceae. In: Kubitzki, K. (ed.). Families and genera of the flowering plants. Springer, Berlin. Pp. 62-70.

Fosberg, F.R. \& Sachet, M.H. 1965. Manual for tropical herbaria. Utrecht, Netherlands. 132p.

Freitas, A.M.M.; Melo, J.I.M. \& Queiroz, L.P. 2008. Boraginaceae A. Juss. do arquipélago de Fernando de Noronha, Pernambuco, Brasil. Iheringia 63: 257-262.

Fresenius, G. 1857. Cordiaceae, Heliotropieae et Borragineae. In: Martius, C.F.P. von (ed.). Flora brasiliensis. Vol. 9. Munchen, Wien, Leipzig. Pp. 1-60.

Gibson, D.N. 1970. Flora of Guatemala: Boraginaceae. Botany 24: 111-167.

Giulietti, A.M.; Conceição, A.A.; \& Queiroz, L.P. 2006. Nordeste semi-árido: caracterização geral e lista das 
espécies fanerógamas. In: Giulietti, A.M.; Conceição, A.A. \& Queiroz, L.P. (eds.). Diversidade e caracterização das fanerógamas do Semi-árido brasileiro. Associação Plantas do Nordeste, Recife. Pp. 15-40.

Guimarães, E.F.; Barroso, G.M.; Ichaso, C.L.F. \& Bastos, A.R. 1971. Flora da Guanabara: Boraginaceae. Rodriguésia 38: 194-220.

Gürke, M. 1893. Boraginaceae. In: Engler, A. \& Prantl, K. (eds.). Vol. 3. Die natürlichen Pflanzenfamilien, Verlag von Wilhelm Engelmann, Leipzig. Pp. 49-96.

Harris, J.G. \& Harris M.W. 2001. Plant identification terminology: an illustrated glossary. Spring Lake Publishing, Spring Lake. 197p.

Johnston, I.M. 1928. Studies in Boraginaceae 7: The South American species of Heliotropium. Contributions from the Gray Herbarium of Harvard University 81: 3-73.

Johnston, I.M. 1930. Studies in Boraginaceae 8: Observations on the species of Cordia and Tournefortia known from Brazil, Paraguay, Uruguay and Argentina. Contributions from the Gray Herbarium of Harvard University 82: 3-89.

Judd, W.S; Campbell, C.S.; Kellogg, E.A.; Stevens, P.F. \& Donoghue, M.J. 2009. Sistemática vegetal: um enfoque filogenético. $3^{\text {a }}$ ed. Artmed, Porto Alegre. $632 \mathrm{p}$.

Maia, G.N. 2004. Caatinga: árvores e arbustos e suas utilidades. D\&Z Computação Gráfica e Editora, São Paulo. 415p.

Melo, J.I.M. 2007a. Taxonomia e distribuição dos gêneros Euploca Nutt. e Heliotropium L. (Heliotropiaceae) para o Brasil. Tese de Doutorado. Universidade Federal Rural de Pernambuco, Recife. 138p.

Melo, J.I.M. 2007b. Uma nova espécie de Tournefortia L. (Boraginaceae s.l.) para o Nordeste do Brasil. Hoehnea 34: 155-158.

Melo, J.I.M. \& Andrade, W.M. 2007. Boraginaceae s.l. A. Juss. em uma área de Caatinga da ESEC Raso da Catarina, BA, Brasil. Acta Botanica Brasilica 21: 369-378.

Melo, J.I.M. \& Lyra-lemos, R.P. 2008. Sinopse taxonômica de Boraginaceae sensu lato A. Juss. no estado de Alagoas, Brasil. Acta Botanica Brasilica 22: 701-710.

Melo, J.I.M. \& Sales, M.F. 2004. Heliotropium L. (Boraginaceae - Heliotropioideae) de Pernambuco, Nordeste do Brasil. Rodriguésia 55: 65-87.

Melo, J.I.M. \& Sales, M.F. 2005. Boraginaceae A. Juss. na região de Xingó: Alagoas e Sergipe. Hoehnea 32: 369-380.

Melo, J.I.M. \& Semir, J. 2008. Taxonomia do gênero Heliotropium L. (Heliotropiaceae) no Brasil. Acta Botanica Brasilica 22: 754-770.

Melo, J.I.M.; Paulino, R.C. \& Silva F.V. 2007. Chave ilustrada para os gêneros de Boraginaceae sensu lato nativos do Brasil. Revista Caatinga 20: 172-180.
Melo, J.I.M.; Silva, L.C.; Stapf, M.N.S. \& Ranga, N.T. 2010. Boraginaceae. In: Forzza, R.C. et al. (eds.). Lista de espécies da flora do Brasil. Jardim Botânico do Rio de Janeiro. Disponível em < http:// floradobrasil.jbrj.gov.br/2010/FB000064>. Acesso em 23 Jan 2011.

Melo, J.I.M.; Silva, L.C.; Stapf, M.N.S. \& Ranga, N.T. 2012. Boraginaceae. In: Forzza, R.C. et al. (eds.). Lista de espécies da flora do Brasil. Jardim Botânico do Rio de Janeiro. Disponível em $<$ http:// floradobrasil.jbrj.gov.br/2010/FB000064>. Acesso em 27 Jul 2012.

Miller, J.S. 1988. A revised treatment of Boraginaceae for Panama. Annals of the Missouri Botanical Garden 75: 456-521.

Miller, J.S. \& Gottschling, M. 2007. Generic classification in the Cordiaceae (Boraginales): resurrection of the genus Varronia P. Br. Taxon 56:163-169.

Mori, S.A.; Mattos-Silva, L.A.; Lisboa, G. \& Coradin, L. 1985. Manual de manejo do herbário fanerogâmico. Centro de Pesquisas do Cacau, Ilhéus. 97p.

Nowicke, J. 1969. Flora of Panama: Boraginaceae. Annals of the Missouri Botanical Garden 56: 33-69.

Sampaio, E.V.S.B. 1995. Overview of the Brazilian caatinga. In: Bullock, S.H.; Mooney, H.A. \& Medina, E. (eds.). Seasonally dry tropical forests. Cambridge University Press, Cambridge. Pp. 34-63.

Smith, L.B. 1970. Boragináceas. In: Reitz, P. R. (ed.). Flora ilustrada catarinense. Herbário Barbosa Rodrigues, Itajaí. Pp. 276-277.

Stapf, M.N.S. 2007. Avaliação da classificação infragenérica de Cordia L. (Cordiaceae) e revisão taxonômica de Cordia sect. Pilicordia DC. para o Brasil. Tese de Doutorado. Universidade Estadual de Feira de Santana, Feira de Santana. $218 \mathrm{p}$.

Szabo, A.V.; Rocha, A.C.S.; Tosato, J.A. de C. \& Barroso, W. 2007. Área de proteção ambiental (APA) Serra Branca Raso da Catarina. In: Marques, J. (ed.). As Caatingas: debates sobre a ecorregião do Raso da Catarina. Fonte Viva, Paulo Afonso. Pp. 21-40.

Taroda, N. 1984. Taxonomic studies on Brazilian species of Cordia (Boraginaceae). PhD Thesis. University of Saint Andrews, Saint Andrews. 231p.

Taroda, N. \& Gibbs, P.E. 1986a. Studies on the genus Cordia L. (Boraginaceae) in Brazil. 1. A new infrageneric classification and conspectus. Revista Brasileira de Botânica 9: 31-42.

Taroda, N. \& Gibbs, P.E. 1986b. A revision of the Brazilian species of Cordia subgenus Varronia (Boraginaceae). Notes from the Royal Botanical Gardens of Edinburgh 44: 105-140.

Taroda, N. \& Gibbs, P.E. 1987. Studies on the genus Cordia L. (Boraginaceae) in Brazil. An outline taxonomic revision of subgenus Myxa Taroda. Hoehnea 14: 31-52. 
Taroda, N. \& Silva, L.C. 2002. Boraginaceae In. Melo, M.M.R.F.; Barros, F.; Wanderley, M.G.L.; Kirizawa, M.; Jung-Mendaçolli, S.L. \& Chiea, S.A.C. (eds.). Flora Fanerogâmica da Ilha do Cardoso. Vol. 9. Pp.105-114.

Thiers, B. 2011 [continuamente atualizado]. Index Herbariorum: A global directory of public herbaria and associated staff. New York Botanical Garden's Virtual Herbarium. Disponível em $<$ http://sweetgum.nybg.org/ih/>. Acesso em 8 Nov 2011.

Tricart, J. 1972. The landforms of the humid tropics, forests and savannas. Geographies for Advanced Study. Longman, London. 306p. 